\title{
ArcheoSciences
}

Revue d'archéométrie

33 (suppl.) | 2009

Mémoire du sol, espace des hommes

\section{How to reconstruct a medieval site: diversity of sources, asset and necessity. The example of Cistercians monasteries in Auvergne (France)}

\section{Emma Bouvard}

\section{OpenEdition}

\section{Journals}

Electronic version

URL: https://journals.openedition.org/archeosciences/1240

DOI: 10.4000/archeosciences. 1240

ISBN: 978-2-7535-1599-4

ISSN: $2104-3728$

\section{Publisher}

Presses universitaires de Rennes

\section{Printed version}

Date of publication: 30 October 2009

Number of pages: $35-37$

ISBN: 978-2-7535-0943-6

ISSN: $1960-1360$

\section{Electronic reference}

Emma Bouvard, "How to reconstruct a medieval site: diversity of sources, asset and necessity. The example of Cistercians monasteries in Auvergne (France)", ArcheoSciences [Online], 33 (suppl.) | 2009, Online since 30 October 2011, connection on 01 February 2022. URL: http:// 


\title{
How to reconstruct a medieval site: diversity of sources, asset and necessity. The example of Cistercians monasteries in Auvergne (France)
}

\author{
Emma BOUVARD*
}

Key words: Cistercians, Hydraulic systems, Landscape, Pedestrian survey, Topography, Middle Ages.

It is difficult to study monastic sites in countries where archives do not exist or are too late to know what the landscape was like during the Middle Ages. That is the case in central France. The old dioceses of Clermont and Le Puy accommodated ten Cistercian monasteries between 1126 and the beginning of the 13th century (Fig. 1). This network has never been studied before and the reason is obvious: none of these abbeys has preserved any of its records. In the best case, there are the ruins and modern registers of accounts (Bouvard, 2006). This is hardly enough for a study of how the white monks colonised an area, and how they lived using the existing resources without worrying about disease. Nonetheless, the sites themselves remain with their geographic characteristics, toponymic testimony and sometimes physical evidence hidden in the landscape. Thus they become the real subject of research which requires a multidisciplinary approach, including special methods like geoarchaeology. The goal of this approach is to understand the adaptation of monasteries to their environment: how sites were chosen and how they were transformed into a place to live for the monks.

First of all, monks rarely chose the location of their monastery, being given land by a noble family on its own property. This is the case in Auvergne. So, they had to adapt their building to natural constraints. When we talk about the monks' choice, it is the way in which they build in a set place and how they transform the landscape to manage it. These transformations remain visible for a long time, even today. Deciphering the anomalies of the landscape provides the opportunity to reconstruct its history before and after the arrival of the Cistercians. The purpose is to create a graphic restitution of the Cistercian site with its hydraulics and economic structure and monastic buildings. At the end, this work will allow a comparison of the ten sites in order to see, if a Cistercian building model exists or not.

Surveys on foot, linked with archival and cartographic researches (lato sensu survey, Verhaeghe, 1986) were undertaken during several weeks last year on seven abbeys in Auvergne. Four will be presented here: Clavas (Bergeron, 2004 and 2002), Bellecombe (Theillère), La Séauve-Bénite (Peyron, 1992) and Feniers (Cantal - Rochemonteix, 1882). The main sources for our investigations are La carte de Cassini, Le Cadastre Napoléonien, topographic maps $(1 / 25000)$ and air photos. The objective was to disco-

* archaeologist, preparing a thesis about Middle Ages Archaeology (directors: Nicolas Reveyron, Université Lumière Lyon 2, UMR 5138 , and Bruno Phalip, Université Blaise Pascal, Clermont II). (emma_bouvard@yahoo.fr) 



Figure 1: Map of the Cistercian abbeys in Auvergne (Emma Bouvard).

ver hydraulic installations testifying to the way in which the Cistercians adaptated to their environment (Bouvard, 2008). Each structure was listed and mapped. These graphic restitutions show huge systems which protect the monk communities from water, while supplying the monasteries with the commodity (Bouvard, 2008).

In this communication I will explain how insignificant monastic sites could be recreated thanks to the method. I 


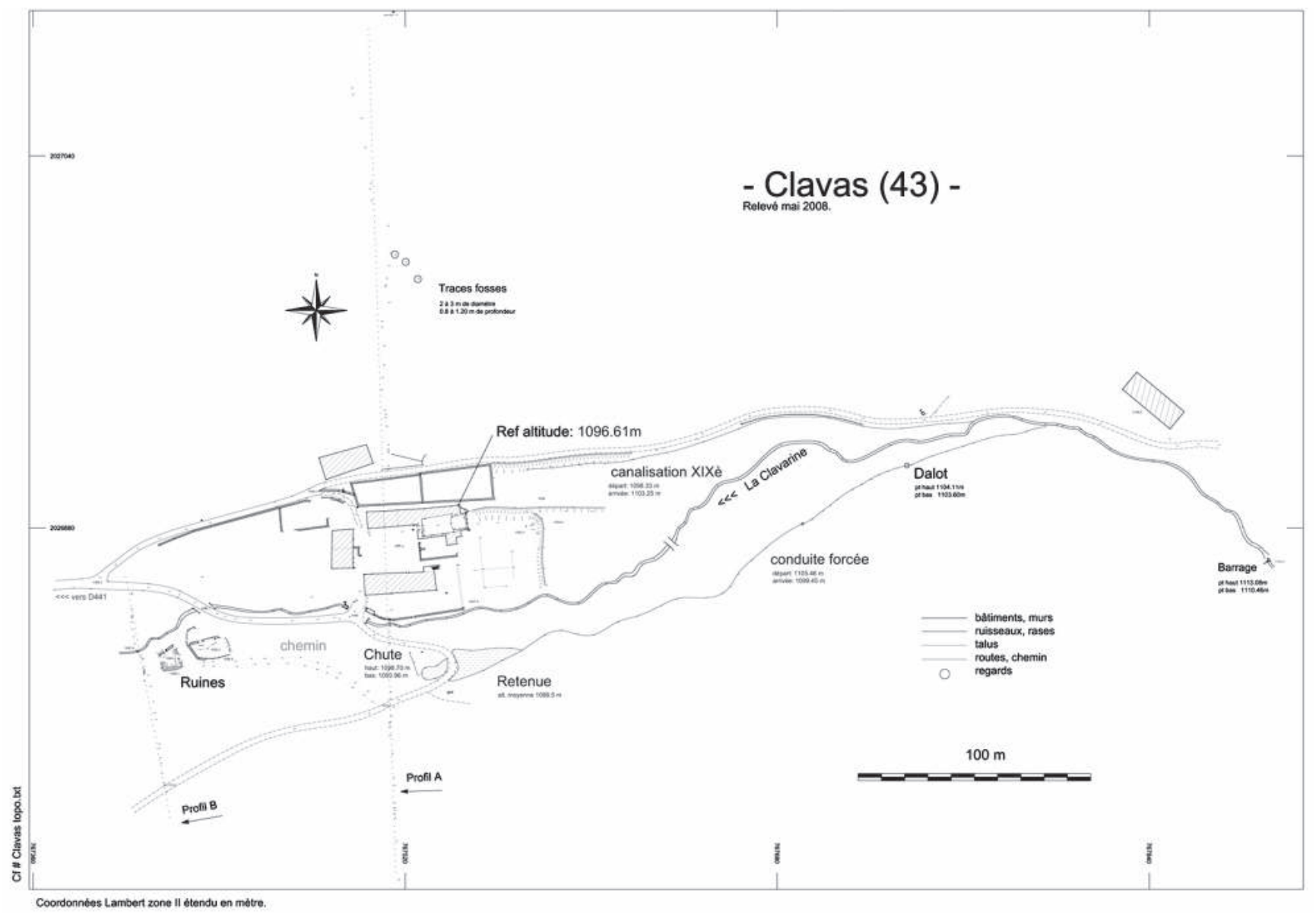

Figure 2: Clavas abbey, Riotord, Haute-Loire, France. Hydraulic system restitution (Patrick Boudon and Emma Bouvard).

will present the results of a land survey which emphasizes the link between Cistercians communities and the landscape, moreover the hydraulic patrimony, because water remains the first condition of settlement (Fig. 2).

\section{References}

Bergeron, R., 2004. L'abbaye cistercienne de Notre-Dame de Clavas aux XVI ${ }^{\mathrm{e}}$ et XVII ${ }^{\mathrm{e}}$ siècles. Cahiers de la Haute-Loire 2004: 59-78.

Bergeron, R., 2002. L'abbaye cistercienne de Notre-Dame-deClavas au XVIII ${ }^{\text {e }}$ siècle. Cahiers de la Haute-Loire 2002: 237264.

Bouvard, E., 2008. Inventaire des infrastructures hydrauliques cisterciennes, levés topographiques des vestiges. Campagne de prospection 2008. Service Régional de l'Archéologie Auvergne, 2 vol.
BouvarD, E., 2006. Opération d'archéologie programmée Abbaye cistercienne de Mègemont, commune de Chassagne, dans le Puy de Dôme. Université Lumière Lyon 2 et Service Régional de l'Archéologie Auvergne.

Bouvard, E., 2005. Opération d'archéologie d'élévation programmée et surveillance de travaux sur l'abbaye de Mègemont (Puyde-Dôme). Université Lumière Lyon 2 et Service Régional de l'Archéologie Auvergne.

Peyron, P., 1002. Abbaye cistercienne de la Seauve-Bénite en Velay, quelques points d'histoire, mémoire dactylographié.

Rochemonteix, A., 1882. L'Histoire de l'abbaye de Feniers ou du Val-Honnête en Auvergne.

Verhaeghe, F., 1986. La prospection "sensu lato": quelques expériences en Flandres (Belgique). La prospection archéologique. Paysage et peuplement, Actes de la table ronde des 14 et 15 mai 1982, Paris, Document d'Archéologie Française n 3, 101-108. 